\title{
Prediction of Height from Percutaneous Tibial Length
}

\author{
Sangeetha. ${ }^{1}$, Tanveer Ahmed Khan ${ }^{2}$ \\ ${ }^{1}$ Assistant Professor, Department of Anatomy, Subbaiah Institute of Medical Sciences, Shivamogga \\ ${ }^{2}$ Associate professor, Department of Anatomy Shimogga Institute of Medical Sciences, Shivamogga.
}

\begin{abstract}
Introduction: Reconstruction of stature from human skeletal remains continues to be an important aspect of anthropology. Of these, lower limb bones have greater contribution to height than upper limb bones.

Materials and methods: The study was done on 100 medical students ( 50 males and 50 females) of the age group 18-22 years. The percutaneous length of both right and left sides was measured in centimetres (cms) using standard measuring tape from the most prominent palpable part of medial tibial condyle to the tip of medial malleolus, in anatomical position with barefoot, on standard beam scale for measuring height to avoid bias.

Results: In the present study using PCTL, the simple regression equation for both sexes, both right and left sides were equated separately. Results obtained were: Males: Right side: $\mathrm{Ht}=83+2.28$ (PCTL) \pm 4.8 , left side: $\mathrm{Ht}=74.7+2.49$ (PCTL) \pm 4.6 ; Females: Right side: $\mathrm{Ht}=103+1.47$ (PCTL) \pm 5.3 , Left side: $\mathrm{Ht}=98.2+1.62(\mathrm{PCTL}) \pm 5.4$.

Conclusion: By using the derived Pearson equation the values obtained are within biological acceptance for both sexes for right and left side. By using the derived regression formula, the height of an individual can be calculated with the help of percutaneous tibial length which is within biological acceptance. The present study can help the anthropologists and forensic experts to predict the stature from given tibia.
\end{abstract}

Key words: Anthropometry, Stature [Height-Ht ], Percutaneous tibial length.

\section{INTRODUCTION:}

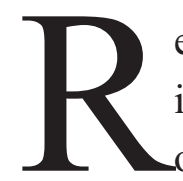

econstruction of stature is one of the important aspects of various parameters individuality of the person from mutilated, decomposed or fragmentary skeletal remains. ${ }^{1-3}$ The stature of an individual may be estimated by adopting anatomical method. This means measurement of any bone or combinations of bone reflects stature. ${ }^{4}$ Quite a number of authoritative work has been done in this field, ${ }^{5}$ yet rarely any work has been done by using the surface length of long limb bones for the purpose of calculation of body height. Keeping this view in mind the present work was taken up among 100 medical students comprising 50 males and 50 females and effort has been made to calculate the body height from Percutaneous Tibial Length (PCTL) as measured by surface anatomical landmarks that is, the distance between the most prominently palpable portion of medial condyle and medial malleolus of tibia based on the regression analysis. ${ }^{1}$ A regression equation formula has been derived for both sexes separately to calculate the body height by using PCTL. 
Sangeetha.V, et.al : Prediction of height from percutaneous tibial length

\section{MATERIALS AND METHODS:}

The present study was conducted in the Department of Anatomy, SUIMS, Shivamogga. The subjects comprised of 100 medical students (50 males and 50 females) age between 18-22 years, the maximum height attained by this age. The standard metric height was measured in centimeters by making the individual to stand on the base board of a standard metric height measuring stand. The individual was instructed to stand barefoot in standard anatomical position and measurement was taken by bringing the horizontal sliding bar close to the vertex. PCTL was measured on both sides from the most prominently palpable portion of medial condyle of the tibia to the medial malleolus with help of standard measuring tape on both sides making foot inverted so as to relax the soft tissue and render the bony landmark more prominent.

\section{RESULTS:}

It was observed that though the standing height of many individuals was found to be the same yet their PCTLs differed. To overcome this biological variation and for the further analysis and interpretation the relevant parameters like the height and PCTL of both sexes were arranged out.

The data thus obtained was analysed for their Mean, Standard deviation, \% Co efficient variation and Standard Error [Table (1, 2, and 3) ].

Table 1. Shows Mean, Standard deviation, \% Co efficient variation for both male and female tibial length.

\begin{tabular}{|c|c|c|c|c|c|c|c|c|}
\hline & \multicolumn{4}{|c|}{ MALE } & \multicolumn{4}{c|}{ FEMALE } \\
\cline { 2 - 9 } & MEAN & SD & RANGE & CV\% & MEAN & SD & RANGE & CV\% \\
\hline AGE & 18.3 & \pm 1.5 & $17-26$ & & 18.8 & \pm 2.4 & $17-22$ & \\
\hline HEIGHT & 168.7 & \pm 6.8 & $150-185$ & 4.1 & 155.3 & \pm 6.3 & $130-171$ & 4.2 \\
\hline $\begin{array}{c}\text { RIGHT } \\
\text { TIBIAL } \\
\text { LENGTH }\end{array}$ & 37.4 & \pm 2.1 & $32-41$ & 5.6 & 35.5 & \pm 2.3 & $30-42$ & 6.5 \\
\hline $\begin{array}{c}\text { LEFT } \\
\text { TIBIAL } \\
\text { LENGTH }\end{array}$ & 37.7 & \pm 2 & $32-41$ & 5.3 & 35.4 & \pm 2.1 & $30-41$ & 5.9 \\
\hline
\end{tabular}

Regression analysis done to establish relationship between height and tibial length and estimation of height for given tibial length - Table 2, 3 .

Table 2. Shows the values of Correlation Coefficient, Regression Co-efficient and Regression Equation (Prediction of height) for both genders.

\begin{tabular}{|c|c|c|c|c|c|}
\hline GENDER & SIDE & $\begin{array}{c}\text { CORRELATION } \\
\text { Co-efficient }\end{array}$ & $\begin{array}{c}\text { Regression } \\
\text { Co- } \\
\text { efficient }\end{array}$ & $\begin{array}{c}\text { Regression } \\
\text { Equation } \\
\text { (Prediction of } \\
\text { height) (cms) }\end{array}$ & SE \\
\hline \multirow{2}{*}{ MALE } & RIGHT & +0.71 & 2.28 & $\mathrm{Ht}=83.3+2.28(\mathrm{TL})$ & 4.8 \\
\cline { 2 - 6 } & LEFT & +0.73 & 2.49 & $\mathrm{Ht}=74.7+2.49(\mathrm{TL})$ & 4.6 \\
\hline \multirow{2}{*}{ FEMALE } & RIGHT & +0.53 & 1.47 & $\mathrm{Ht}=103.0+1.47(\mathrm{TL})$ & 5.3 \\
\cline { 2 - 6 } & LEFT & +0.54 & 1.62 & $\mathrm{Ht}=98.2+1.62(\mathrm{TL})$ & 5.4 \\
\hline
\end{tabular}

Table 3. Shows r-values and p-values of both males and females in relation to height and tibial length of both sides.

\begin{tabular}{|c|c|c|c|c|}
\hline \multirow{2}{*}{ Relationship between } & \multicolumn{2}{|c|}{ MALES } & \multicolumn{2}{c|}{ FEMALES } \\
\cline { 2 - 5 } & r-values & P-values & r-values & P-values \\
\hline Ht and Right Tibial length & +0.71 & $<0.001$ & +0.53 & $<0.001$ \\
\hline Ht and Left Tibial length & +0.73 & $<0.001$ & +0.54 & $<0.001$ \\
\hline
\end{tabular}

Regression coefficient, represented as a change in height per unit change in the tibial length was highly significant for both sexes. Thus the predicted height could be approximated when the percutaneous tibial length is given within the observed range. The results of study are shown in the form of scatter diagrams - Graphs 1,2,3 \& 4. 


\section{Graph 1. Relationship between left tibial length} and height - males

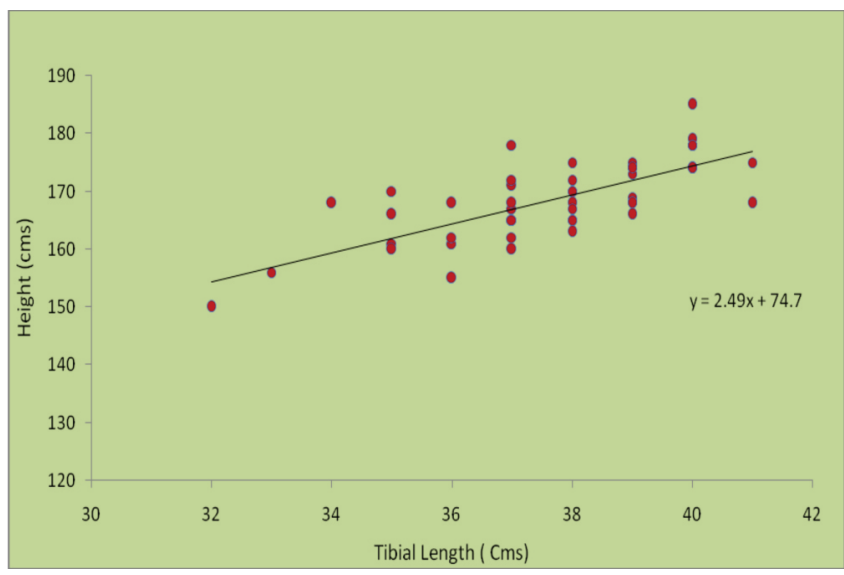

Graph 2. Relationship between right tibial length and height - Males

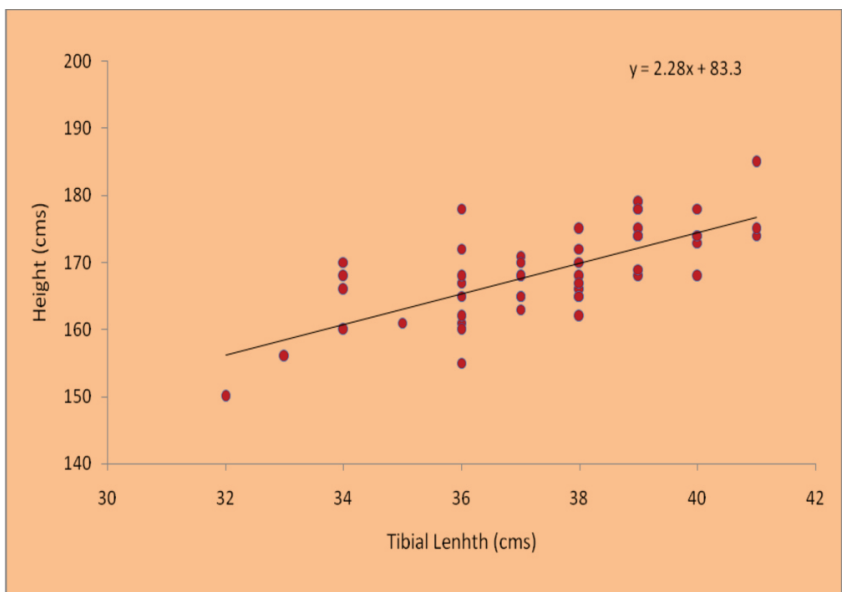

Graph 3. Relationship between right tibial length and height - Females

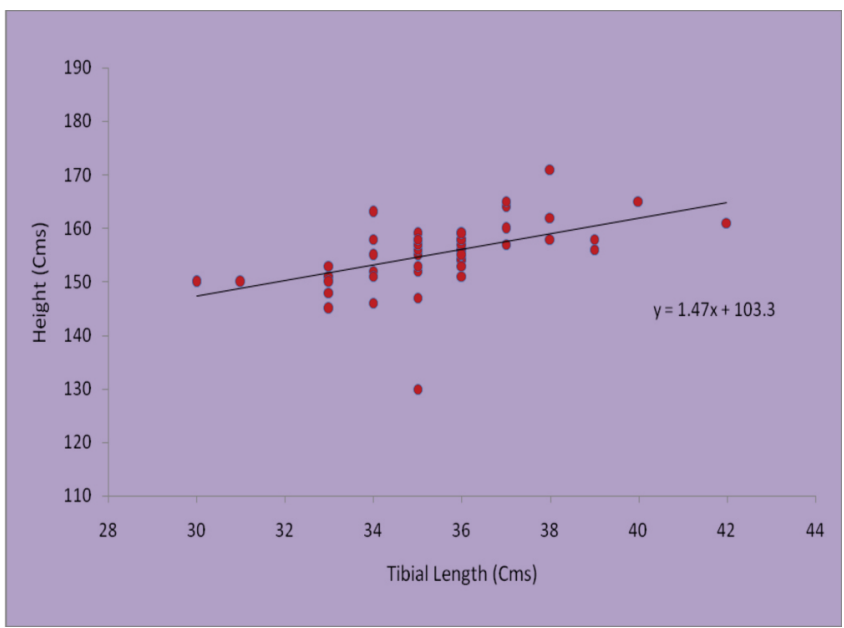

Graph 4. Relationship between left tibial length and height - Females

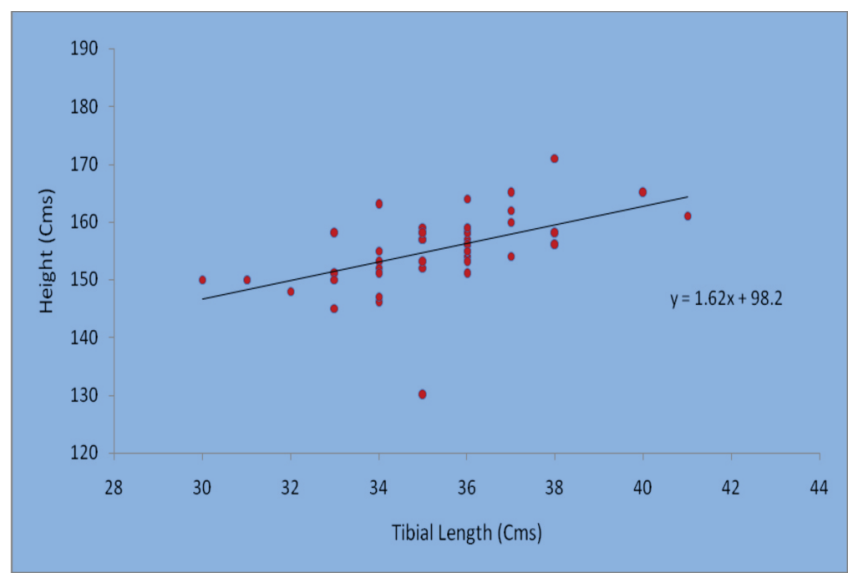

\section{DISCUSSION:}

In the present study using PCTL the simple regression equation for both sexes, both right and left sides were equated separately. The following equations were derived:

\section{MALE}

RIGHT SIDE : $\mathrm{Ht}=83+2.28(\mathrm{PCTL}) \pm 4.8$

LEFT SIDE $\quad: \mathrm{Ht}=74.7+2.49(\mathrm{PCTL}) \pm 4.6$

\section{FEMALE}

RIGHT SIDE : $\mathrm{Ht}=103+1.47(\mathrm{PCTL}) \pm 5.3$

LEFT SIDE $\quad: \mathrm{Ht}=98.2+1.62(\mathrm{PCTL}) \pm 5.4$

By using the derived Pearson equation the values obtained are found to be within biological acceptance for both sexes for right and left side in. The present study shows similar values with those of other studies (Table 4).

Hence it can be inferred that the derived regression equation of my study can be used for prediction of height in anthropological studies and by forensic experts. 
Sangeetha.V, et.al : Prediction of height from percutaneous tibial length

Table 4: Shows values of present study in comparison to other studies.

\begin{tabular}{|c|c|c|c|c|c|}
\hline AUTHOR & POPULATION & $\begin{array}{c}\text { MEAN } \\
\text { DIFFERENCE }\end{array}$ & SD & t & SIG \\
\hline Trotter and Gleser & Puertoricans & -5.24 & 2.39 & -17.30 & 0.000 \\
\hline I Can Pelin $^{7}$ & Turkish & 0.18 & 2.80 & 0.57 & 0.572 \\
\hline Present study $^{7}$ & $\begin{array}{c}\text { South Indian } \\
\text { population }\end{array}$ & 2.0 & 2.4 & 5.12 & 0.001 \\
\hline Allbrook & Nilo Hamit & -11.60 & 2.46 & -18.90 & 0.000 \\
\hline${ }^{1}$ & Felkka & -5.14 & 2.59 & -7.95 & 0.000 \\
\hline Breitinger & German & -7.71 & 2.44 & -12.64 & 0.000 \\
\hline
\end{tabular}

Table 4 shows the values obtained in the present study, a mean of 2.0, in South Indian population is almost similar to other studies by I Can Pelin ${ }^{7}(0.18)$ in the Turkish. The SD of present study was 2.4 which is similar to studies of other authors, 2.44 by Breitinger ${ }^{8}, 2.46$ by Allbrook 1 and 2.39 by Trotter Gleser. $^{6}$

\section{CONCLUSION:}

In the present study the mean height for 50 males and 50 females was $169 \mathrm{cms}$ and $155 \mathrm{cms}$ respectively. The mean PCTL in males was about $37 \mathrm{~cm}$ on the right side, $38 \mathrm{~cm}$ on the left side whereas for the females $36 \mathrm{~cm}$ on the right side and $35 \mathrm{~cm}$ on the left side. The estimated values were within biological acceptance with standard error of 4.8 on right side and 4.6 on left side in males. In female the standard error was 5.3 on right and 5.4 on left. Hence, the derived regression equation of my study can be used for prediction of height in anthropological studies and by forensic experts.

\section{REFERENCES:}

1. Krogman W.M, Iscan M.Y. The human skeleton in forensic medicine. 2nd ed Springfield: Charles C Thomas, 1986; 164.

2. Mohanty N.K. Prediction of height from percutaneous tibial length among Oriya population. Forensic Science International. 1998 Dec 21; 98(3): 137-41.

3. Hepworth S.M. Determination of age in Indians from a study of calcification of the long bones. Ind Med Gaz. 1929March; 64(3): 128.

4. Nath B.S. Use of lower limb measurements in reconstructing stature among Shia Muslims. Internet Journal of Biological Anthropology. 2009Feb13;2(2): 86-99.

5. Stehman C.R. Bed side estimation of patient height for calculating ideal body weight in the Emergency Department. Journal of Emergency Medicine. 2011; 4(1):97-110.

6. Trotter M. and Gleser G.C. A re-evaluation of estimation of stature based on measurements of stature taken during life and of long bones after death. Am J Phys Antrhopol. 1958; 16(1): 79-123.

7. Pelin I. C. and Duyar I. Estimation of stature from tibial length: a comparison of methods. J Forensic Sci 2003 July; 48(4): 708-12.

8. Breitinger E. Zur Berechnung der Korperhohe aus den langen Glied-massenknochen weiblicher skelette. Anthropol Anzeiger 1937; 14: 249-74.

Received on 15/11/2017 Revised on 09/02/2018 Accepted on 23/02/2018 